\title{
CORRESPONDENCE
}

\section{Smoking and Cancer}

SIR,-In his letter (Nature, 231, 543; 1971) on smoking and lung cancer, Dr Sterling states that he had set up a panel to provide authoritative guidance on the link between smoking and disease, and invited Dr Cuyler Hammond to meet this panel. He also requested Dr Hammond to provide the panel with the unpublished data from his own studies: Dr Hammond refused.

He then develops a highly personal attack on Dr Hammond in which he implies that this refusal casts serious doubt on Dr Hammond's reports on the association between smoking and lung cancer.

More seriously, however, Dr Sterling's letter also implies that this refusal by $\mathrm{Dr}$ Hammond casts similar doubt on other studies on the relationship between lung cancer and smoking. Thus, Dr Sterling impugnes the integrity and competence of the numerous scientists and committees in many countries who have reviewed exhaustively the extensive data published on this subject ${ }^{1,2}$. If Dr Sterling disagrees with their conclusions he should do so in a carefully documented critique of all the published data rather than by singling out Dr Hammond's study for personal criticism.

I suspect the reason for Dr Hammond's unwillingness to meet with Dr Sterling's panel is that he does not feel that his time would be best spent discussing and presenting data to yet another group of individuals apparently unfamiliar with the material in the widely explored area of cigarettes and lung cancer. There must be few experts in this field who have studied the literature and not yet reached a decision.

Thus, I believe that Dr Hammond's colleagues will consider that Dr Sterling's tasteless attack constitutes a form of blackmail, and that he was fully justified in his decision not to discuss his data with Dr Sterling's panel. Further, many will draw the conclusion that this attack implies that any scientist who fails to make his data available to any Tom, Dick or Harry is lacking in credibility. This attempt to discredit scientific data and conclusions by character assassination through inference should not be part of the modern scientific approach, and I am surprised that this letter was published in Nature.

I have disagreed from time to time with the American Cancer Society on its comments on individual scientific papers, but I have not doubted its good faith and the basic correctness of its wish to bring to public notice the danger of a popular habit, which at best is a thankless task.

Lastly, Dr Sterling should confirm that neither he, nor his department nor his research, are supported by the grant reported to have been made recently to his university by certain industrial interests.

$$
\begin{aligned}
& \text { Yours faithfully, } \\
& \text { JoHN HIGGrNSON }
\end{aligned}
$$

World Health Organization, International Agency for Research on Cancer,

16 Avenue Maréchal Foch, 69 Lyon (6ème)

${ }_{1}$ Smoking and Health Report of the Advisory Committee to the Surgeon General of the Public Health Service (Public Health Service Publication No. 1103, 1964).

2 Smoking and Health Now (A Report of the Royal College of Physicians, 1971).

\section{Defoliation by Gypsy Moth}

SIR,-In the article "St George versus a Gypsy Moth" (Nature, 231, 142; 1971), Nature shows signs of adopting the style of its American contemporary, a consummation devoutly to be abhorred. Your Washington correspondent says that the battle of words over the gypsy moth "has been a walk-over for those who argue that gypsy moths may in all likelihood be less pernicious than the measures taken to exterminate them". Who decided this? On June 24, 1970, the New York Times, which is scarcely a friend of pesticides, reported from Riverhead, Long Island (p. 59): " . . The caterpillars arrived in large cans and plastic bags brought to the legislative session by more than 50 irate residents of the communities of Shirley, Mastic and Ridge. The residents demanded immediate emergency action to curb this year's invasion which is, according to some agricultural experts, the largest since the moth was introduced into this country in 1869 . 'We are in a state of emergency', Mrs Helen Gaylord, of 32 Maple Avenue, in Shirley, told the legislature, 'Our children cannot go out. Our pools are finished for the summer. It's a question of survival-the caterpillars or us'."

Nature states that the USDA, "like many bureaucracies, is kept in motion by force not of reason but of habit", a generalization that also could be unkindly applied to Washington correspondents. Your correspondent also asks the rhetorical question: "Why does the Department of Agriculture persist in pursuing a programme of which the objectives are ill defined, the benefits clearly temporary, the biological consequences unknown because of inadequate research, and the intellectual foundations so shoddy as to destroy any pretensions to academic respectability the department might still hold ?"

The objective of the programme is clearly defined-kill gypsy moth caterpillars. All benefits can be described as temporary, and all biological consequences as unknown. The final phrase is merely name-calling. Stripped of its emotional rhetoric, the article in Nature is a one-sided plea for not interfering with "the natural evolution which must take place while gypsy moths find their natural niche" (column 3 ). This is the standard neo-Luddite plea against pest control. It is voiced most commonly by dwellers in air-conditioned urban buildings. Meanwhile, after a century to "find their natural niche", the gypsy moths are on the move, and are defoliating vast new areas of forest and woodland ${ }^{1}$.

\section{Yours faithfully,}

Thomas H. Jukes

Berkeley,

California

1 Nichols, J. O., Pennsylvania Forests, Fall 1970 (Pennsylvania Forests Association, 5221 E. Simpson Street, Mechanicsburg, Pennsylvania).

\section{Reports und Publications}

not included in the monthly Books Supplement Great Britain and Ireland

Forestry Commission. Booklet No. 28: Gwydyr Forest in Snowdonia-a History. By Donald L. Shaw. Pp. vii $+107+26$ plates. 40p net. Bulletin No. 42: Conifer Woolly Aphida (Adelgidae) in Britain. By C. I. Carter. Pp. iv +51. 75p net. Forest Record No. 74: Development of Glasshouse Techniques for Early Progeny Test Procedures in Forest Tree Breeding. By R. B. Herbert. Pp. 34. 20p net. Forest Record No. 75: Design, Construction and Maintenance of Earth Dams and Excavated Ponds. By E. F. Granfield. Pp. 75. 17t p net. Booklet No. 30: Metric Conversion Tables for Forestry. Compiled by J. E. Everard. Pp. $v+71$. Sop net. (London: HMSO, 1971.) [245 Report 1969/1970. Pp. 149. (London: Queen Mary College, 1971.)
[255 Philosophical Transactions of the Royal Society of London. A: Mathematical and Physical Sciences. Vol. 269, No. 1199 (13 May 1971): A Discussion on Architectural Aerodynamics. Organized by M. J. Lighthill and A. Silverleaf. Pp. 321-554+ plates 8-12. Splashing of Water Drops on Solid and Wetted Splashing of Water Drops on Solid and Wetted By $Z$. Levin and P. V. Hobbs. Pp. 555-586+ plates 13-16. f1.10; $\$ 2.85$. (London: Royal Society of London, 1971.) 